Kalamatika: Jurnal Pendidikan Matematika Volume 5, No. 1, April 2020, pages 69-82

\title{
STUDENTS’ ABILITY TO READ STATISTICAL DIAGRAM
}

\author{
Sugeng Sutiarso \\ University of Lampung, Jl. Sumantri Brojonegoro No. 1, Bandar Lampung, Indonesia \\ sugeng.sutiarso@fkip.unila.ac.id
}

\begin{abstract}
Reading diagrams is an important ability needed by college students, particularly to writing their thesis. This ability could help students in describing and communicating the results of their research. Conversely, the inability to read diagrams causes errors in interpreting the results of the research. This descriptive qualitative study aims to describe the ability of students to read diagrams in terms of gender differences and the tendency to choose problems between bar/line diagrams, and the reasons behind the difficulties for students reading diagrams. This study involved 25 students who were finishing their thesis in Mathematics Education, Faculty of Mathematics and Natural Sciences, University of Lampung. Research data were collected using test and interview instrument. This table reading test consists of 2 essay questions, which are reading bar and line diagrams. Semi-structured interviews aimed at completing the diagram reading test data. The results showed that students'ability both male and female to read diagrams was classified as moderate, the ability to read bar charts of female students was higher than that of male students but the ability to read line diagrams of male students was higher than female students, female students tend to choose bar diagrams rather than line diagrams while male students tend to choose line diagrams rather than bar diagrams, and the cause of difficulties in reading diagrams for female students were errors in understanding the meaning words while male students were errors of logical thinking in associating data with other data.
\end{abstract}

\section{ARTICLE INFORMATION}

\begin{tabular}{lll}
\hline Keywords & & Article History \\
\cline { 1 - 1 } Literacy & & Submitted Mar 11, 2020 \\
Diagrams & Revised Apr 27, 2020 \\
Statistical thinking & Accepted Apr 28, 2020 \\
\hline
\end{tabular}

\section{Corresponding Author}

Sugeng Sutiarso

University of Lampung

Jl. Sumantri Brojonegoro No. 1, Bandar Lampung, Indonesia

Email: sugeng.sutiarso@fkip.unila.ac.id

\section{How to Cite}

Sutiarso, S. (2020). Students' Ability to Read Statistical Diagram. Kalamatika: Jurnal Pendidikan Matematika, $5(1), 69-82$. 


\section{INTRODUCTION}

Statistics is one part of mathe taught at all levels of the school, because statistics are widely used in daily life. In addition, statistics is not only taught to students majoring in mathematics, but to all students outside the department of mathematics (Yenni \& Andriyani, 2019). Diagrams are an important part of statistical material. In the 2013 curriculum, the diagram; or often also called graphics, has been taught in schools ranging from grade 3 elementary school to grade 12 high school, even to the college. The teaching of diagrams at all levels of education is intended so that students can have communication skills and mathematical representation (NCTM, 2000; Sumarmo, 2012). The ability to read diagrams must be possessed by students. Because the diagram can function as a communication medium of a situation or condition, and vice versa a situation condition can be represented by a diagram.

Reading diagrams consists of 2 words that form it, namely reading and diagrams. Reading is interpreted as a thought process to understand and interpret the meaning of the writing/symbol (Dalman, 2013). Literally, diagrams are pictures (blurred, sketched) that show or explain a situation/condition based on the data (KKBI, 2020). Means, reading diagrams is a thought process to understand and interpret the meaning of a situation/condition based on the data. In statistics in several types of diagrams, including bar charts, lines and circles (Sutiarso, 2011). Each diagram has a different form and purpose. Bar charts are shaped in sections to show the development of the value of an object in a certain time span. Line diagram in the form of a line to show the observations of the value of an object at a certain time. A circular circle diagram to show the percentage of a part.

Diagrams are widely used in educational activities and daily life. In educational activities, diagrams are used by students when learning mathematics (statistics). In daily life, diagrams are often found on information boards, activity reports or research (thesis). Diagrams are widely used in education and daily life because of the benefits of these diagrams, which present too much or complicated data to be adequately explained in less space (Slutsky, 2014), facilitate the presentation of data (Yulianti et al., 2015), and display data at a glance, facilitates comparisons, and can reveal trends and relationships in the data (In \& Lee, 2017). Although diagrams have been widely used by students in learning statistics, several studies have suggested that there are still many students having difficulty reading or understanding diagrams. 
Some research on the ability to read diagrams has been done by researchers ranging from elementary school students to college students. Specially research on college students was reported by Subekti \& Kusuma (2016) that some students still weak in understanding the symbol on the frequency histogram/polygon. Takaria \& Talakua (2018) stated that students have difficulty understanding normal curve digrams due to weak concepts about data distribution. Rafianti, et al. (2018) reported that more than $30 \%$ of students mistakenly interpret the circle's circles because they have not precisely determined the ratio of a data to all data. Andoko \& Pamungkas (2018) founded that only $10 \%$ of college students were able to interpret data from a given case. Based on some of these studies, it appears that the ability of students in reading diagrams is low. Although research on reading diagrams has been done by researchers, this research is limited to the description of reading ability and the factors causing difficulty of reading diagrams. The research also has not analyzed the tendency to choose questions between the bar and line diagrams and has not differentiated the ability to read between gender differences.

Analysis of the tendency to choose questions is considered important because by knowing the tendencies of these students can be considered by the teacher in choosing a material over other materials. The choice of material on this other material is part of student interest in learning. A student who has an interest in a subject matter, the student will have a high motivation to learn the material, or in other words, a high-interest student in learning can encourage high motivation too (Cahyono, 2018; Shin et al., 2019). Likewise, analyzing gender differences will make it easier for teachers to apply effective teaching models or methods. Because some studies mention that there are differences in abilities between male and female students in certain sections, namely mathematical problem solving (Wardani, 2014), understanding mathematical concepts (Kurniasi, 2016), mathematical learning achievement (Anjum, 2015), student creativity profile in solve problems (Febryana, 2018), mathematical reasoning (Salmina \& Nisa, 2018), and mathematical proof (Sutiarso, 2019). This study aims to describe the ability of students to read diagrams in terms of gender differences and the tendency to choose questions between bar/line diagrams, as well as the causes of difficulties for students reading diagrams. The selection of students who write their thesis is based on the consideration that when students doing their thesis a lot of data will be processed and concluded. 


\section{METHOD}

This type of research is descriptive qualitative which describes the results of the study without any treatment. This research involved 25 college students (8 male and 17 female) of Mathematics Education Study Program, FKIP, University of Lampung, who were writing their thesis in odd semester of the academic year 2019/2020. The selection of these thesis finishing students as research subjects is based on considerations, namely (a) college students are people who study at the highest level of education, (b) thesis writing is an activity that involves data processing and concludes it. Research data were collected through test and interview instruments. Before being used in this research, the instument was validated by two experts (colleague) and it was stated that both were valid.

This table reading assessment consists of 2 essay questions, which are reading bar and line diagrams. The test questions on the two questions are the same, which is 4 items. However, it is different in the diagram shown, which is the bar and line diagram (Figure 1). On the test sheet, it does not write the number of questions, and students can choose the questions solved first between the bar and line diagrams.

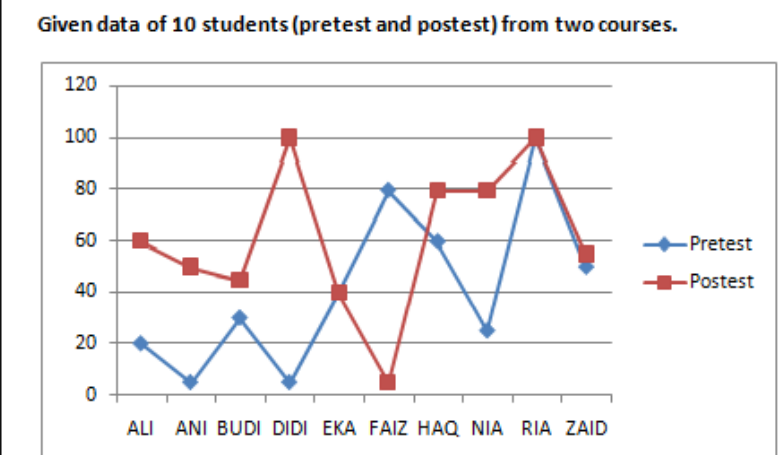

Based on the two diagrams, answer the following question (describe the reasons):

1. Who is the student with the highest grade increase?

2. Who is the student with the lowest rade increase?

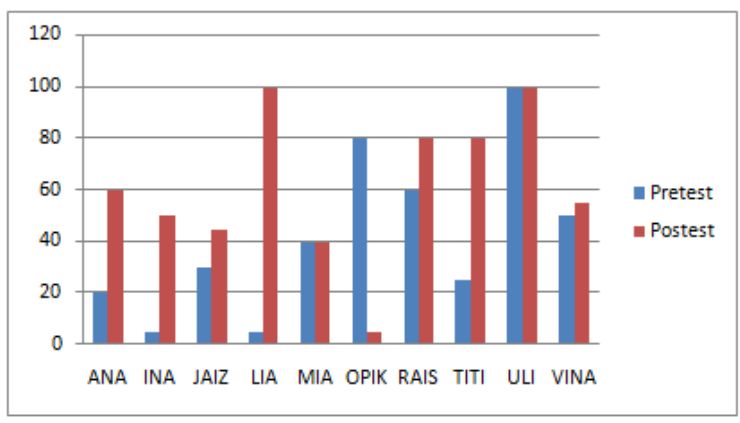

3. Who is the student with a reasonable grade increase?

4. Who is the student with an unreasonable grade increase?

Figure 1. Questions on Reading Diagram Ability Test

The interview is in the form of semi-structured which aims to complete the result data by reading the diagram test. The interview question is what is the (logical) reason for choosing to solve the problem of a diagram rather than another diagram? The data result obtained through test and interview were analyzed with descriptive statistics. Specifically, for the test results, the average answer score is classified based on the following level of interpretation as seen on table 1 . 
Table 1. Average Score and Interpretation Levels of the Answers

\begin{tabular}{crr}
\hline No & Average Score $(\mathrm{x})$ & Level \\
\hline 1 & $0,00<\mathrm{x} \leq 1,33$ & Low \\
2 & $1,33<\mathrm{x} \leq 2,66$ & Moderate \\
3 & $2,66<\mathrm{x} \leq 4,00$ & High \\
\hline
\end{tabular}

\section{RESULTS AND DISCUSSION}

\section{Ability to Read Diagram as A Whole}

The results of college students' ability to read this diagram are based on the test reading bar and line diagrams. Each test contains 4 items with the same questions. The results of the analysis of the answers given by 25 students showed the average score of students' ability to read bar charts 1,52; line diagram 1,36; and both 1,44 (maximum score of 4). The average score of the students' abilities is stated in figure 2 below.

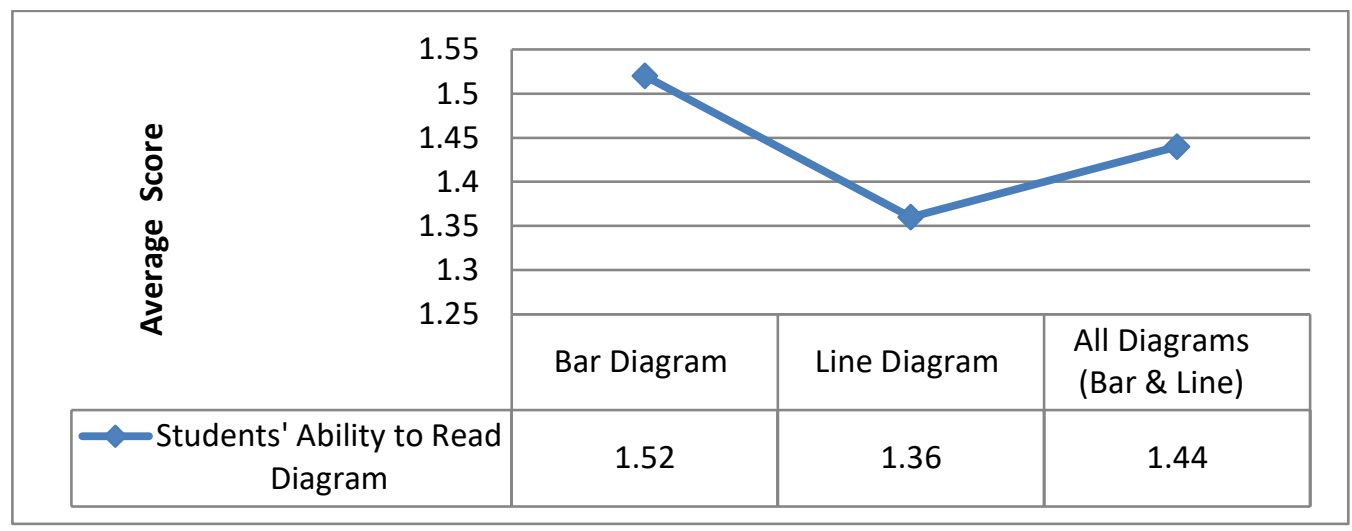

Figure 2. Students' Ability to Read Diagrams

Based on figure 2, several findings are obtained, namely (a) as a whole, the ability of students to read diagrams is classified as moderate (average score 1,44), and (b) the ability to read bar charts is higher than line charts. These results indicate that the ability of students (thesis authors) in reading diagrams is classified as moderate. Even though reading diagrams is an important ability and highly will be found by college students in writing a thesis. In writing a thesis, students collect and process data. Furthermore, to ensure that the data is easily understood, the results of data processing are represented as diagrams, and vice versa interpreting the diagram above the previous data. Subsequent findings show that students' ability to read bar charts is higher than reading line diagrams. Besides, the results obtained that there are college students' answers that are not consistent in completing bar and line diagrams. The 
students' answers to the two questions should be the same even though the diagrams are different.

The results of the analysis of the student answer sheet found 2 main errors that caused the students difficulty in reading the diagrams, namely errors understanding the meaning of words and errors of logical thinking in associating data with other data. Generally, female students make errors understanding the meaning words, whilemale students make errors of logical thinking in associating data with other data.The following are examples of student answers based on these 2 errors, namely:

1. Errors understanding the meaning of words

What is meant by misunderstanding the meaning of words is the words 'lowest' and 'reasonable'. Some students understand the word 'lowest' is the difference in value between posttest and pretest more than 0 (zero and negative values are not included), and some other students understand the word 'lowest' is the difference in value between posttest and zero pretests. The truth is, the word 'lowest' means the smallest difference in value between posttest and pretest (including zero and negative values). Likewise, most students understand the word 'reasonable' is understood by students if there is an increase in scores between posttest and pretest, and the increase is not too high. The correct understanding is that the word 'reasonable' means an increase between posttest and posttest, except when the pretest gets the maximum but when the posttest gets the minimum value.

Understanding the meaning of words is a complicated activity. To understand the meaning of words properly, a person needs to know the conceptual, compositional, and operational approach of a word (Chaer \& Muliastuti, 2014). The conceptual approach states that each word inherently contains a concept, idea or thought about something that exists, happens or takes place in the real world. Componential approach states that each word's meaning consists of several components which as a whole form the meaning of the word. The operational approach states that the meaning of a new word is clear when the word has been used in the context of a particular sentence. Based on the three approaches, the meaning of a word can be understood if someone knows the ideas contained in the word, the components that form the word, and the relationship with other words.

Understanding the meaning of words also requires knowledge of the meaning of lexical and grammatical words (Sarnia, 2015). The meaning of the lexical word is the meaning of the 
word that is written in the dictionary. The meaning of the grammatical word is the meaning of the word formed using the said word under the correct grammar. This means a word can be interpreted correctly if someone has sufficient knowledge about the meaning of words as written in the dictionary, and knowledge of the word meanings by correct grammar. Furthermore, to understand the meaning of words, knowledge of the meaning of denotation and connotation is needed (Widiyawati et al, 2017). The meaning of denotation is the actual meaning of the word and does not contain any particular feeling or value. The meaning of connotation is the meaning contained in a word that has a sense of value both positive and negative. So, when interpreting a word, a person needs to know the true meaning and sense value of the word. The example of errors in understanding the meaning of the words 'lowest' and 'reasonable' from student answers can be seen in figure 3 below.

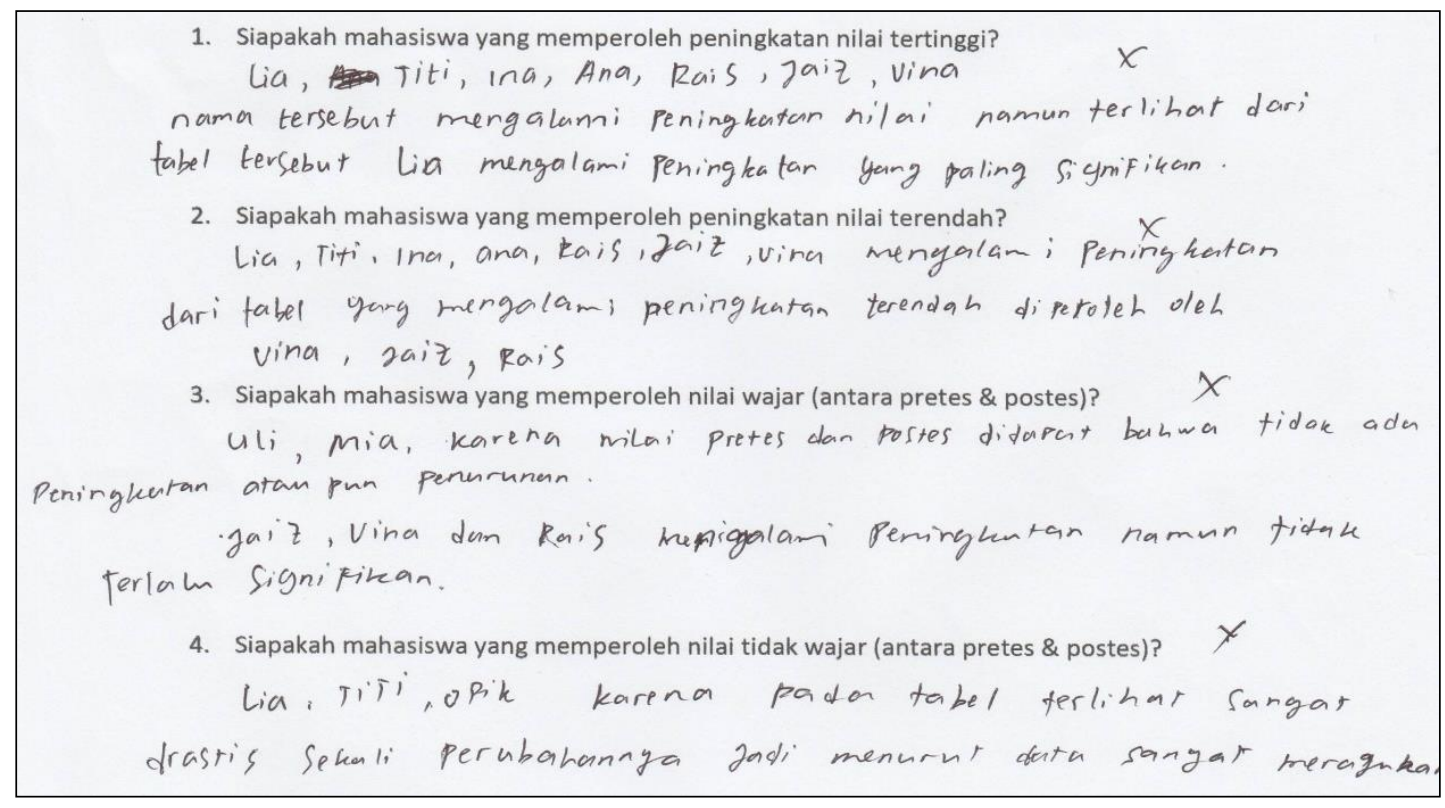

Figure 3. Examples of Mistakes in Understanding the Word Meanings

2. The error in logical thinking in associating data with other data.

This error occurs when the students associate the increase in the highest and lowest score, as well as associating the reasonable and unreasonable values. All students answered correctly to the question "Who gets the highest increase?", but all students answered incorrectly to the question "Who got the lowest increase?". Likewise, all students answered correctly to the question "Who gets the fair value?", but all students answered incorrectly to the question "Who gets the fair value?". The two questions are actually conflicting questions; that is, the first answer 
is the opposite of the second answer and vice versa. If students can think logically then both of these questions should be answered correctly, or if they are answered wrong then the other should be wrong. The example of logical thinking errors in associating data with other data can be seen in Figure 4 below.

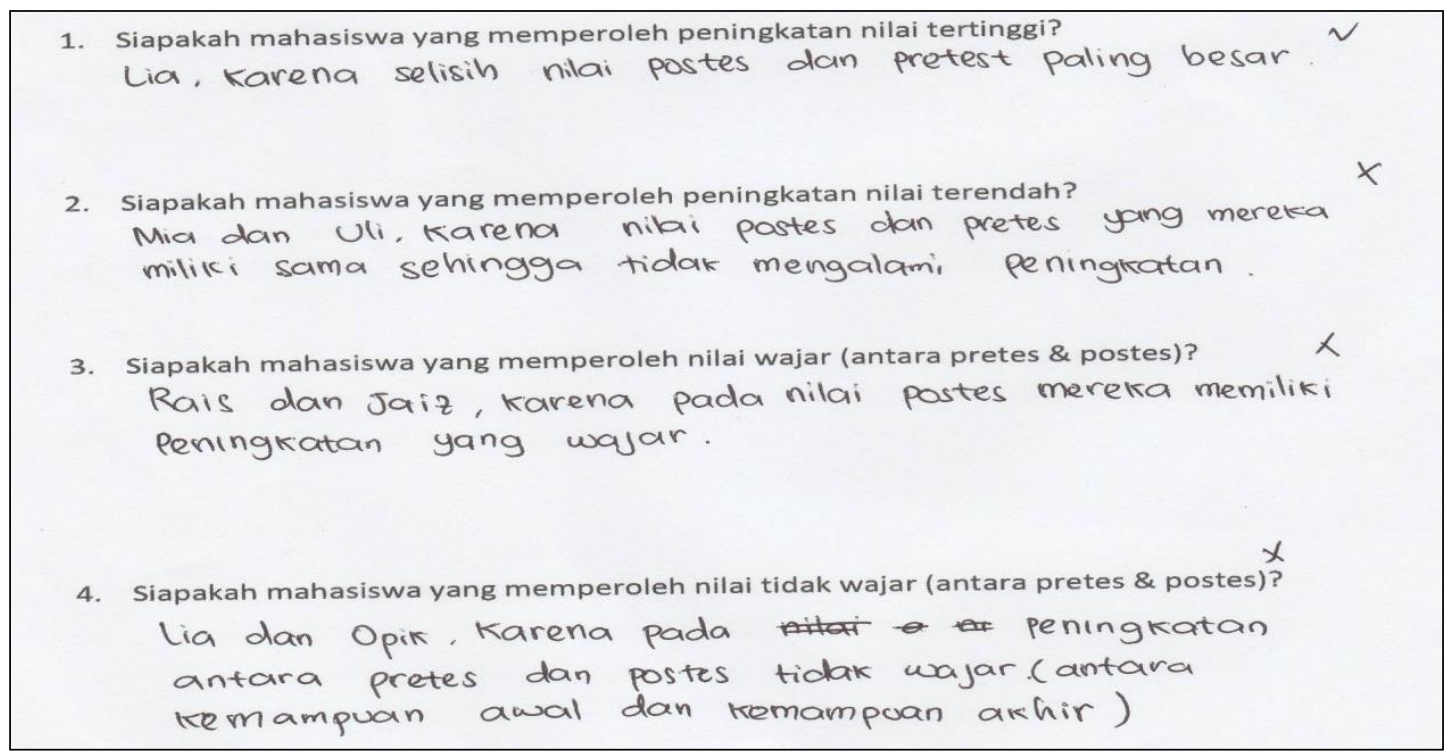

Figure 4. Examples of Errors on Logical Thingking on Data Interrelation

\section{Ability to Read Diagrams Based on Genders}

Overall, the average score of college students' ability to read diagrams based on gender differences showed that female students (average score of 1,47) obtained a higher score than male students (average score of 1,38). Moreover, if seen from the table question it is found that the ability to read bar diagrams of female students is higher than that of male students, but the ability to read line diagrams of male students is higher than female students with a small gap between these two. In summary, the average scores of female and male student abilities are shown in Figure 5 below. 


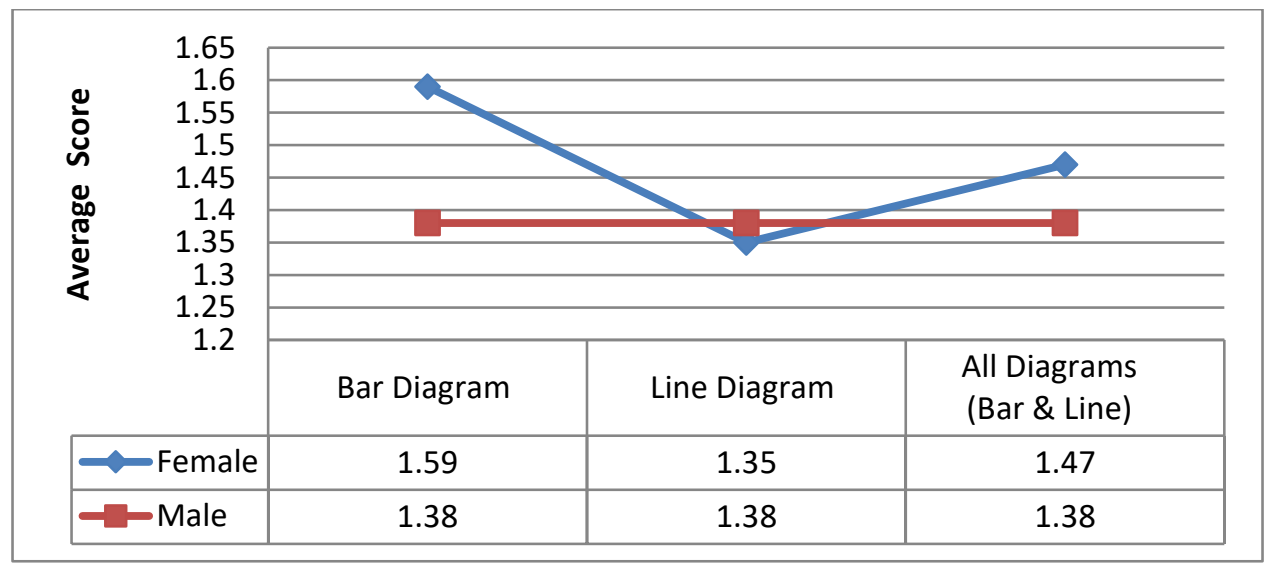

Figure 5. The ability to Read Diagrams Based on Genders

Based on Figure 5, it shows that female students more easily understand bar charts than male students, while male students more easily understand line charts than female students. These results provide information (new findings) that female students more easily read discrete data, and male students more easily read continuous data. Discrete data is defined as calculated data, and continuous data is measured data (Sutiarso, 2011). Based on these definitions, it means that discrete data represent rounded data and continuous data describes data that are fractional (interval). In other words, female students tend to more easily understand rounded data, and male students tend to more easily understand fraction data. This result is in line with Sutiarso (2019) which states that male students tend to have higher original (imaginative) thinking abilities than female students, while female students tend to have higher fluency abilities (routines) than male students. These results may be related to the fact that when the students face objects (data) that are not fixed (fractions), imaginative abilities are needed, and vice versa when dealing with objects that are fixed (round) routine abilities are required.

\section{Ability to Read Diagrams Based on Selection of Questions}

Overall, the average score of students' ability to read diagrams based on the tendency to choose questions obtained by students who choose bar diagram questions have higher mean scores than line charts, and students who choose line charts have higher mean scores than bar charts. These results indicate that the ability of students following the tendency to choose questions between bar/line diagrams. Based on gender, female students tend to choose bar diagrams rather than line diagrams while male students tend to choose line diagrams rather than bar diagrams. The average score of students' ability to read diagrams based on the choice of questions is shown in Figure 6 below. 


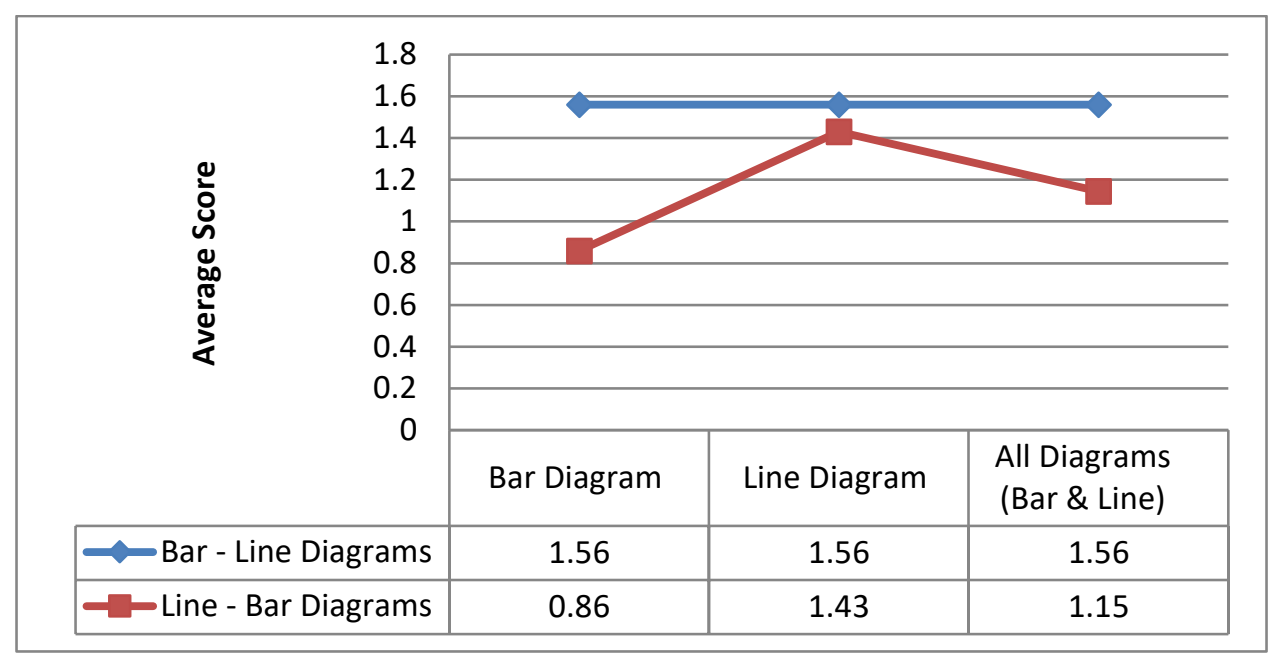

Figure 6. Ability to Read Diagrams Based on Selection of Questions

Based on Figure 6, shows that the ability to read diagrams following the tendency to choose the diagram problem and this tendency is related to the interest in an object. Likewise, in learning, that one's learning interest greatly influences the learning outcomes. Interest is a feeling of preference and a sense of interest in a thing or activity without the need of anyone asking for it (Slameto, 2010). It can be interpreted as a student who is interested in learning will learn with pleasure, thus resulted in a positive impact on learning outcomes. The results of the study showed that the higher interest possessed, the higher the learning outcomes, and conversely the lower learning interest, the lower the learning outcomes will be (Pangestu et al., 2015; Otoo et al., 2018).

The results of interviews with students (male and female students) about the reasons for the tendency to choose a line diagram or bar chart problem is that the line diagram problem is easier to solve than a bar diagram or vice versa. The tendency of students to choose questions is based on the assumption that it is 'easier' to solve line diagram problems than bar charts, or vice versa. The following is an interview conversation about the reasons for the tendency to choose the questions (lecturer and students):

Lecturer: "Why do you choose line diagram problems first over bar charts?" Student_1 (male): "I prefer line charts, I think it's easier"

Lecturer: "Why do you choose a bar chart problem over line diagram?" Student_2 (female): "I prefer the bar charts. Bar charts are easier to understand rather than line charts" 


\section{CONCLUSION}

The ability to read diagrams is one of the important knowledges for students, especially students who are writing their thesis. When writing a thesis, students must be able to collect and process data, as well as represent data in the form of diagrams. The inability to read this diagram shows the inability of students to communicate the results of their research. The results of this study can be used as evaluation material for lecturers in teaching statistical material (diagram material), including the use of learning methods for female and male college students. The results of this study indicate that (1) students' ability both male and female to read diagrams was classified as moderate, (2) the ability to read bar charts of female students was higher than that of male students but the ability to read line diagrams of male students was higher than female students, (3) female students tend to choose bar diagrams rather than line diagrams while male students tend to choose line diagrams rather than bar diagrams, and (4) the cause of difficulties in reading diagrams for female students were errors in understanding the meaning words while male students were errors of logical thinking in associating data with other data.

\section{ACKNOWLEDGMENTS}

On this occasion, the author would like to thank to Dr. Caswita (head of department on mathematics and natural education science education) for their assistance and facilities, as well as students of mathematics education Unila. May Allah SWT blesses you for the good deeds you have done.

\section{REFERENCES}

Andoko \& Pamungkas, A. S. (2018). Kajian Literasi Statistik Mahasiswa dalam Membaca, Menyajikan Data dan Menafsirkan Data. Prosiding Seminar Nasional Pendidikan Matematika FKIP UIR 2018, 29-30 Agustus 2018, 8-14.

Anjum, S. (2015). Gender Difference in Mathematics Achievement and Its Relation with Reading Comprehension of Children at Upper Primary Stage. Journalof Education and Practice, 6(16), 71-75.

Cahyono, A. E. (2018). Identifikasi Faktor Internal yang Mempengaruhi Motivasi Belajar Mahasiswa IKIP PGRI Jember. Jurnal Fektor, 15(1), 18-25. 
Chaer, A., \& Muliastuti, L. (2014). Makna dan Semantik. Jakarta: UT Press.

Dalman. (2013). Keterampilan Membaca. Jakarta: Raya Grafindo Persana.

Febryana, D. (2018). Profil Kreativitas Siswa dalam Menyelesaikan Soal Segitiga dan Segiempat Ditinjau dari Gender . Siska Journal of Mathematics Education, 4(1), 50-58.

In, J., \& Lee, S. (2017). Statistical Data Presentation. Korean Journal of Anesthesiology, 70(3), 267-276.

KKBI. (2020). Received January 1, 2020, dari http://KKBI.web.id/diagram

Kurniasi, E. R. (2016). Profil Pemahaman Matematis Mahasiswa Pendidikan Matematika Ditinjau dari Jenis Kelamin. Jurnal Prima, 5(2), 1-7.

NCTM. (2000). Principles and Standars for School Mathematics. Reston: NCTM.

Otoo, D., Iddrisu, W., Kessie, J., \& Larbi, E. (2018). Structural Model of Students' Interest and Self-Motivation to Learning Mathematics. Hindawi Education Research International, 2018, 1-10.

Pangestu, A. D., Samparadja, H., \& Tiya, k. (2015). Pengaruh Minat terhadap Hasil Belajar Matematika Siswa SMA Negeri 1 Uluiwoi Kabupaten Kolaka Timur. Jurnal Penelitian Pendidikan Matematika, 3(2), 17-26.

Rafianti, I., Setiani, Y., \& Novaliyosi. (2018). Profil Kemampuan Literasi Kuantitatif Calon Guru Matematika. Jurnal Penelitian dan PembelajaranMatematika, 11(1), 63-74.

Salmina, M., \& Nisa, S. K. (2018). Kemampuan Penalaran Matematis Siswa Berdasarkan Gender pada MateriGeometri. Numeracy , 5(1), 41-48.

Sarnia. (2015). Polisemi dalam Bahasa Muna. Jurnal Humanika , 15(3), 1-16.

Shin, D., Lee, H., Lee, G., \& Kim, G. (2019). The Role of Curiosity and Interest in Learning and Motivation. Cambridge: Cambridge University Press. 
Slameto. (2010). Belajar dan Faktor-Faktor yang Mempengaruhinya. Jakarta: PT. Rineke Cipta.

Slutsky, D. J. (2014). The Effective Use of Graphs. Journal of Wrist Surgery, 3(2), 67-68.

Subekti, F.E. \& Kusuma, A.B. (2016). Deskripsi Kemampuan Komunikasi Matematis Ditinjau dari Rasa Percaya Diri Mahasiswa. Jurnal Euclid, 3(1), 377-525.

Sumarmo, U. (2012). Pendidikan Karakter serta Pengembangan Berpikir dan Disposisi Matematik dalam Pembelajaran Matematika. Makalah Disajikan dalam Seminar Pendidikan Matematika di NTT Tanggal 25 Februari 2012.

Sutiarso, S. (2011). Statistika Pendidikan dan Pengelolaannya dengan SPSS . Bandar Lampung: Aura Printing \& Publishing.

Sutiarso, S. (2019). The Ability of Students' Mathematical Proof in An Introduction to Group Theory in terms of Gender Differences. Jurnal Pendidikan MIPA, 20(2), 60-67.

Takaria, J.\& Talakua, M. (2018). Kemampuan Literasi Statistik Mahasiswa Calon Guru Ditinjau dari Kemampuan Awal Matematika. Jurnal Kependidikan, 2(2), 395-408.

Wardani, A. K. (2014). Kemampuan Pemecahan Masalah berdasarkan Perbedaan Jenis Kelamin. Jurnal Pendidikan Matematika STKIP PGRI Sidoarjo, 2(1), 99-108.

Widiyawati, Sumarti, \& Riadi, B. (2017). Diski pada Kuliah Umum Etika Frans Magnis Suseno SJ serta Komplikasinya . Jurnal Kata (Bahasa, Sastra, dan Pembelajaran), 5(2), 1-12.

Yenni \& Andriyani, R. (2019). Bahan Ajar Statistika Berbasis Generative Learning untuk Meningkatkan Kemampuan Pemahaman Matematis. Kalamatika: Jurnal Pendidikan Matematika, 4(2), 151-162.

Yulianti, Hartono, Y., \& Santoso, B. (2015). Desain Pembelajaran Berbasis Proyek pada Materi Penyajian Data di Kelas IX. Numeracy, 2(2): 1-2. 
82 KALAMATIKA, Volume 5, No. 1, April 2020, pages 69-82 